\title{
Summer distribution patterns of southern resident killer whales Orcinus orca: core areas and spatial segregation of social groups
}

\author{
Donna D. W. Hauser ${ }^{1, *}$, Miles G. Logsdon², Elizabeth E. Holmes ${ }^{3}$, \\ Glenn R. VanBlaricom ${ }^{1}$, Richard W. Osborne ${ }^{4}$ \\ ${ }^{1}$ Washington Cooperative Fish \& Wildlife Research Unit, School of Aquatic \& Fishery Sciences, University of Washington, \\ Box 355020, Seattle, Washington 98195, USA \\ ${ }^{2}$ School of Oceanography, University of Washington, Box 355351, Seattle, Washington 98195, USA \\ ${ }^{3}$ Northwest Fisheries Science Center, National Marine Fisheries Service, 2725 Montlake Blvd. East, Seattle, \\ Washington 98112, USA \\ ${ }^{4}$ The Whale Museum, PO Box 945, Friday Harbor, Washington 98250, USA
}

\begin{abstract}
A diverse range of marine wildlife species respond to dynamic environments and patchy resources with variations in their distribution pattern. For many cetacean species, highly structured social systems add to the complexity of modeling distribution patterns and understanding the effects on population viability. Southern resident killer whales Orcinus orca are comprised of 3 distinct, yet cohesive, matrilineally related social groups called pods, and recent population declines have prompted conservation actions in the US and Canada, including listings as an endangered species. Habitat protection is a major component of each listing, yet little is known about pod-specific core areas or patterns of space use for this population. Using $6 \mathrm{yr}$ of sighting information within the inshore waters of Washington and British Columbia, we modeled pod-specific summer distribution and measured relative variation in the density of sightings on a uniform spatial grid. Our results indicate that the pods exhibit complex, non-uniform summer space-use patterns. Although some regions are used in common by all pods, some areas are used almost exclusively by individual pods or certain combinations of pods, indicating specialization to particular areas. Our results indicate that pod groups display variable patterns of space use; therefore, each pod may experience unique habitat conditions or exposure to potential risk factors. This result is highly relevant when considering podspecific mortality rates and the relative contribution of each pod to overall population trends. Our analyses highlight important areas of conservation, and provide the necessary description for podfocused conservation initiatives.
\end{abstract}

KEY WORDS: Orcinus orca $\cdot$ Southern resident killer whale $\cdot$ Distribution $\cdot$ Kernel density $\cdot$ Spatial analysis $\cdot$ Core area $\cdot$ Social structure

\section{INTRODUCTION}

Marine organisms are confronted with dynamic environmental conditions and patchy resources that range across spatial and temporal scales. Many marine predators, such as cetaceans, respond to ecosystem variability by modifying their distribution pattern to limit reductions in survival or reproductive success (Forney 2000). Describing distribution patterns of cetaceans becomes more complicated when considering the social organization and behavior of these species (Redfern et al. 2006), and within a given species, space use can vary for distinct populations and population segments (e.g. Whitehead 1997). For example, habitat preferences of the humpback whale Megaptera novaeangliae on a wintering ground are 
influenced by social structure in that mother-calf groups prefer consistent habitat types while paired adults or competitive groups have variable preferences (Ersts \& Rosenbaum 2003). Different uses of space among cetacean social units can result from unique responses to physical habitat characteristics, anthropogenic and naturally occurring risk factors, and other conditions driving animal distribution. For distinct vocal clans of sperm whales Physeter macrocephalus, differences in habitat use and movement patterns are related to variable foraging success that can be linked to effects of climate change on biological production (Whitehead \& Rendell 2004). Social structure and associated variations in spatial distribution can affect reproductive success and gene flow among population subgroups, making social structure an important variable for space use analyses (Dobson \& Poole 1998). Thus unique distribution patterns among different population subgroups may be a critical component of space-based management and conservation initiatives. This study focused on the description of core areas and comparison of space use among distinct population subgroups of the endangered killer whale Orcinus orca population in the coastal eastern North Pacific.

Sympatric mammal- and fish-eating ecotypes of killer whales have been distinguished in the eastern North Pacific (Ford et al. 1998, 2000). Early studies of fish-eating killer whales in this region used individual recognition to describe a complex social system with multiple levels of stable interactions among individuals (Bigg et al. 1990). The so-called southern resident killer whale (SRKW) population of fish-eating whales, found in summer within inshore marine waters of Washington, USA and British Columbia, Canada is composed of 3 matrilineally related subgroups (pods) identified as J, K, and L. Among SRKW, pods are thought to be long-term cohesive social groups, with individuals spending $\geq 50 \%$ of their time together and with both sexes exhibiting limited dispersal from natal pods (Bigg et al. 1990). Every individual can be identified using photographic identification of unique pigmentation patterns and dorsal fin morphology (Bigg et al. 1987, Baird \& Stacey 1988), and several decades of annual censuses provide thorough long-term demographic knowledge of population trends (Ford et al. 2000). Recent declines in the SRKW population have prompted several conservation listings in both the US and Canada, including listing the population as endangered under the US Federal Endangered Species Act and Canada's Federal Species At Risk Act (Baird 2001, Krahn et al. 2004). Identifying key areas within the SRKW range and protecting critical habitat are central components of SRKW recovery planning in both the US and Canada.
In the summer, SRKW are found within the inshore waters of Washington and British Columbia (Ford et al. 2000, Hauser 2006), but the usage of specific areas within these waters is poorly understood, especially variations among the 3 pods. There are seasonal variations among pods in the proportion of time spent within the inshore waters of Washington and British Columbia and some evidence of niche partitioning on a coarse scale (Osborne 1999). SRKW pods have distinct acoustic call types, population trajectories, and mortality trends (Hoelzel \& Osborne 1986, Ford 1991, Krahn et al. 2004), which suggest that these unique social groups may also display fine-scale variations in their distribution patterns. The different SRKW pods may not be using space proportionately, and core areas, or areas used most frequently, may contain important resources (Samuel et al. 1985).

Our goal was to describe variations in space use and quantify core areas among SRKW pods using 6 yr of sighting data collected throughout their summer range. Although pods are distinct units and individuals in a pod always travel together, a pod may travel alone or with another pod. When analyzing pod space use, we need to consider both individual and combined pods. A pod's distribution pattern may change based on whether it is alone or in a pod group. Thus, we used conventional and innovative approaches for describing pod distribution to (1) cluster groups of SRKW pod combinations based on similar space use patterns, (2) describe and quantify distribution patterns and core areas among pod groups, and (3) identify locations of spatial overlap and specialization among pod groups.

\section{MATERIALS AND METHODS}

SRKW location data. From May to September in each of the years from 1996 to 2001, SRKW daily locations were reported by an organized spotting system of commercial whalewatchers functioning cooperatively to find whales for their customers. Canadian and US vessels and at least one shore-based observer searched Washington and British Columbia inshore waters for killer whales daily from 08:00 to 17:00 h (Fig. 1). Approximately every $30 \mathrm{~min}$, the sighting network recorded pod identification ( $\mathrm{J}$ pod, K pod, L pod, a combination of SRKW pods if animals were co-mingling, unidentified killer whales, or mammal-eating killer whales), time, and location for each killer whale sighting. Locations were recorded as the center point of a standardized grid (see below). Potential limitations and biases related to the use of these data for distribution studies were evaluated, and we followed the data use guidelines developed by Hauser et al. (2006) to ensure high pod identification accuracy. Hauser et al. 


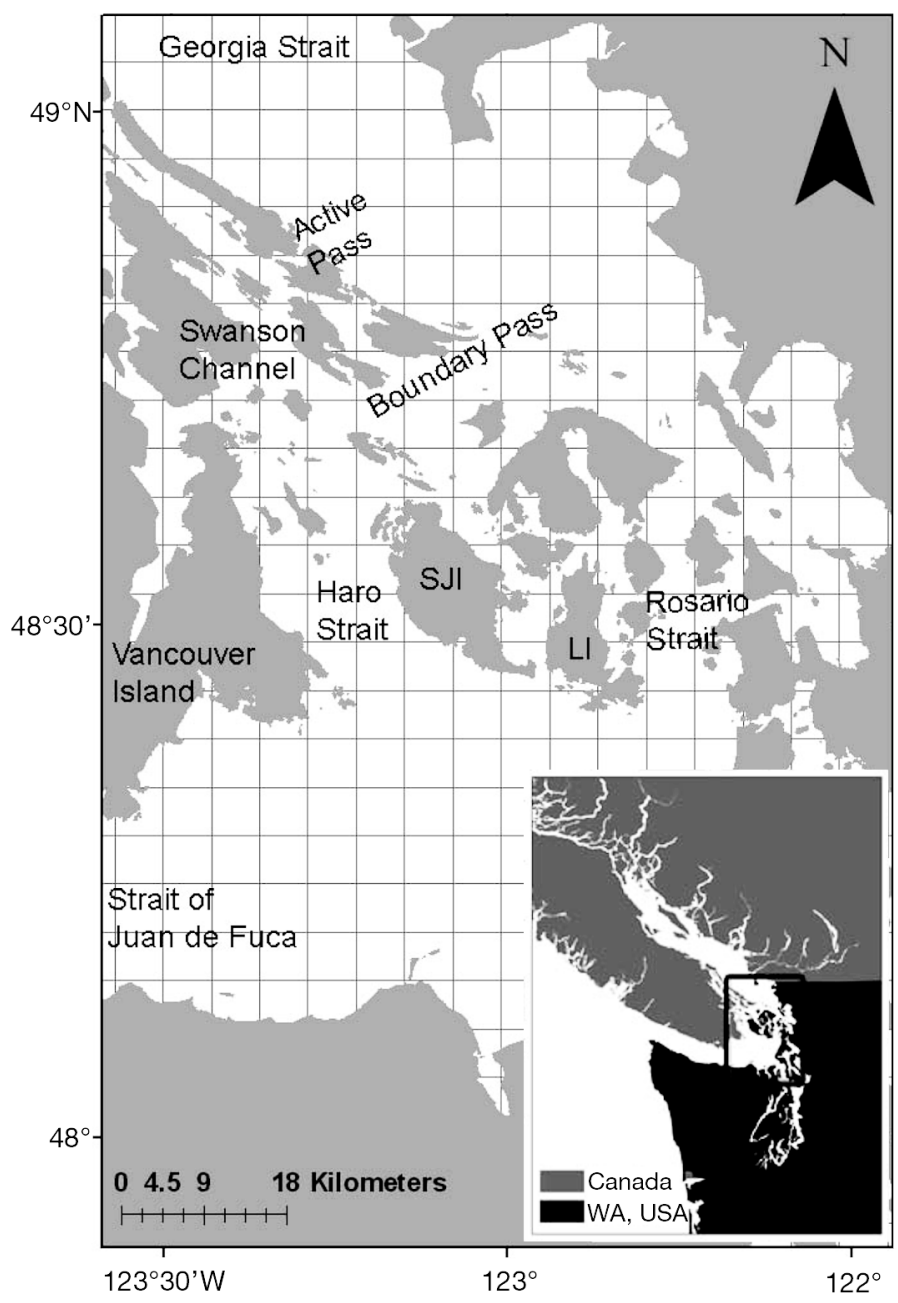

Fig. 1. Orcinus orca. Washington and British Columbia inshore waters generalized into sampling grids for southern resident killer whale (SRKW) sightings by commercial whalewatchers. SJI: San Juan Island, WA; LI: Lopez Island, WA

(2006) provide a more detailed discussion of these data, including daily schedule, number of vessels, and organization of the observer network. This prior work concluded that whalewatcher effort throughout the study region was consistent enough that if SRKW were located anywhere within the study region during the day, they would be seen. The minimum number of days that whales were available to whalewatchers was specified by the number of days between the first and last sighting each year. Using this information, we determined the percentage of days that each pod was located within the study region as well as the number of sightings per pod.

Describing space use: kernel density. Sightings by commercial whale watchers within Washington and British Columbia inshore waters were assigned to the corresponding center points of standardized $5 \mathrm{~km}^{2}$ cells (Fig. 1). Frequency of sightings within each grid was then modeled using fixed kernel density estimators in ArcGIS, v. 9.1 (ESRI). Fixed kernel density estimators represent the 2-dimensional relative frequency of summer pod locations across the $6 \mathrm{yr}$ data period and describe the configuration of variable space use for each pod (Silverman 1986, Worton 1989). Kernel density estimators have been used extensively in wildlife distribution studies, with recent application to several cetacean species (e.g. Heide-Jorgensen et al. 2002, Hobbs et al. 2005).

Distinguishing groups from pod combinations. SRKW pods frequently combine for short periods, and many sightings of combined pods exist in our database. Therefore, we also considered similarities in distribution for pod combinations. We used kernel density to model and compare distribution for each pod and pod combination ( $\mathrm{J}$ alone, $\mathrm{K}$ alone, $\mathrm{L}$ alone, $\mathrm{J}$ and $\mathrm{K}, \mathrm{J}, \mathrm{K}$ and $\mathrm{L}$, J and L, and $\mathrm{K}$ and $\mathrm{L}$ ). Visual comparison of the resulting density calculations of the 7 pod combinations indicated overlap in distribution patterns. Next, we used 2 independent multivariate approaches, hierarchical cluster analysis and ordination (nonmetric multidimensional scaling) to test whether the 7 pod combinations could be clustered into groups without losing information. Both approaches are useful for simplifying highly correlated, complex datasets such as ours. When considered as a pair, clustering and ordination techniques are effective methods for checking the adequacy and mutual consistency of results from both analyses (Clarke \& Warwick 2001).

To facilitate comparisons among combinations, each pod combination's kernel density was normalized from 0 to 1 , where 1 represents the maximum density value. Additionally, density values were standardized for pod abundance in each cell of the study region as suggested for species similarity analyses (Clarke \& Warwick 2001). Thus standardized, geographically referenced density distributions of space use were compared among pod combinations. For multivariate analyses, Bray-Curtis similarity coefficient values (Bray \& Curtis 1957) were calculated between pod combinations to create a similarity matrix for both hierarchical cluster and nonmetric multidimensional scaling (NMDS) analyses. The BrayCurtis similarity coefficient measured the similarities in distribution between pairs of pod combinations by calculating the absolute value of the sum of differences divided by the sum of the totals for all pod combinations in different cells (Clarke \& Warwick 2001). Similarity equaled zero if the 2 pod combinations had no cells in common and ranged up to 100 if the density values of the pod pair were equal across all cells.

Hierarchical cluster analysis was used to group pod combinations with respect to similarity in density distribution patterns. Hierarchical agglomerative methods 
using the group-average link on the similarity matrix (McGarigal et al. 2000, Clarke \& Warwick 2001) were used to describe groups of pod combinations that tend to co-occur similarly across cells in the study region. The resulting clusters were overlaid on the nonmetric multidimensional scaling ordination results. NMDS is wellsuited to many types of ecological community data because these data can be nonparametric and do not necessarily have continuous scales or linear relationships among variables (Clarke 1993). Through an iterative process, NMDS was used to compute coordinates for each pod combination in multidimensional space. Stress values were calculated as a measure of goodness-of-fit for the nonparametric regression, where low stress is optimal (i.e. $<0.1$ is considered a good final ordination result and $<0.05$ is excellent) (Kruskal 1964, Clarke 1993, Clarke \& Warwick 2001). To effectively choose an appropriate number of pod groupings, cluster results were compared with the final NMDS ordination and examined for mutual consistency.

Modeling pod-specific space use and core areas. The groupings of pod combinations (pod groups) that resulted from clustering and NMDS were used for all subsequent comparisons of pod-specific space use. For each pod group, the sightings of the newly grouped pod combinations were pooled and kernel density was recalculated. For direct comparisons of kernel density distributions among pod groups, the density of observations for each pod group was classified into 5 density classes, ranging from low to high density. Quantile separation was used to select breakpoints such that there were an equivalent number of observations in each of the 5 density classes. Locations with no sightings (i.e. zero density) were not included in the normalization. This allowed for comparisons among pod groups across the range of low to high density classes as well as comparisons of the highest density regions. To determine core space use, we delineated core areas as the newly classified highest density regions, representing locations where 80 to $100 \%$ of sightings occurred. Core space thus represents the most frequently used regions by each pod group.

We applied several techniques to compare core and total space use among pod groupings. First, to describe variations in use of particular areas and differences in the extent of distribution for each pod group, kernel density was mapped and classified as the proportion of maximum density for each pod group. Next, we used the density, normalized (as described in the preceeding paragraph) into the 5 classes, to determine areas where one pod group used the space more than the other groups. We identified all of the locations categorized in the highest density classes $(>60 \%$ of sighting density) for one pod group that were simultaneously in the lowest density classes ( $<20 \%$ of sighting density) for all other groups. The identified cells were mapped, and generalized polygons were added over the identified locations to indicate the region where one group specialized. We also determined common space use patterns among pod groups by mapping all of the locations where each pod group shared the exact same density classification. Variations in core area among pod groups were compared by mapping the unique and overlapping core areas for each group. Finally, we measured the geographic distribution of each pod group and pooled SRKW locations by calculating the mean center and directional distribution.

The geographic distribution is a spatial statistic analogous to the more conventional biostatistical measurement of a mean and standard deviation for a data set. Spatial statistics, including calculation of a mean center and directional distribution, is an extension of traditional statistics that incorporates the distribution of descriptive values and the arrangement of those values in space (Haining 2003). We considered the description of kernel density value in spatially explicit locations for each pod group. The mean center represents the average $x$ - and $y$-coordinate for all cells with a density $>0$, weighted by the density value (Mitchell 2005). Directional distribution describes variation and spatial trend around the mean center as standard distance and spatial orientation from the mean center, weighted by density values $>0$ (Mitchell 2005).

\section{RESULTS}

Whalewatchers searched for whales on a total of $776 \mathrm{~d}$ during the 6 yr study period and SRKW were observed on 611 of those days (Table 1). Sightings first occurred in May in each year except 1996 and ended in September in each year except 1998. SRKW were within the study region during an average of $79.25 \%$ search days each year, ranging from $64.5 \%$ in 2000 to $96.7 \%$ in 2001. Additionally, each pod combination occurred within the region at varying levels (Table 2). Least common were KL and JL pod combinations, which were each only seen on approximately $6 \%$ of the available days, while the individual $\mathrm{J}$ and $\mathrm{L}$ pods were seen most frequently, on approximately $23 \%$ and $40 \%$ of available days, respectively.

\section{Similarities among pod combinations}

Visually, kernel density distributions of several of the pod combinations appeared to have very similar distribution patterns. Accordingly, hierarchical cluster analyses of similarities in distribution patterns among pod combinations revealed 3 groups with statistically 
similar density patterns: a J group, a K group, and an L group. NMDS results corroborated clustering results and provided a 2-dimensional graphical configuration (stress $=0.04$ ) of space use similarities among pod combinations (Fig. 2). The J group included observations of the $\mathrm{J}$ pod alone, the $\mathrm{J}$ and $\mathrm{K}$ pods together, and the $\mathrm{J}$ and $\mathrm{L}$ pods together. The K group comprised the K pod alone and the $\mathrm{K}$ and $\mathrm{L}$ pods together. The L group comprised the $\mathrm{L}$ pod alone and the $\mathrm{J}, \mathrm{K}$, and L pods together. In subsequent spatial analyses, these 3 new pod groups were used and sightings of each pod combination within a group were pooled together. After pooling, the most sightings were in the L group (61.0\% of available days), followed by the J group (48.8\%) and the $\mathrm{K}$ group $(20.2 \%)$ (Table 2$)$.

\section{Pod group-specific variations in distribution}

We found several similarities and variations in space use among pod groups (Fig. 3). All pod groups exhibited similarly high density throughout Haro

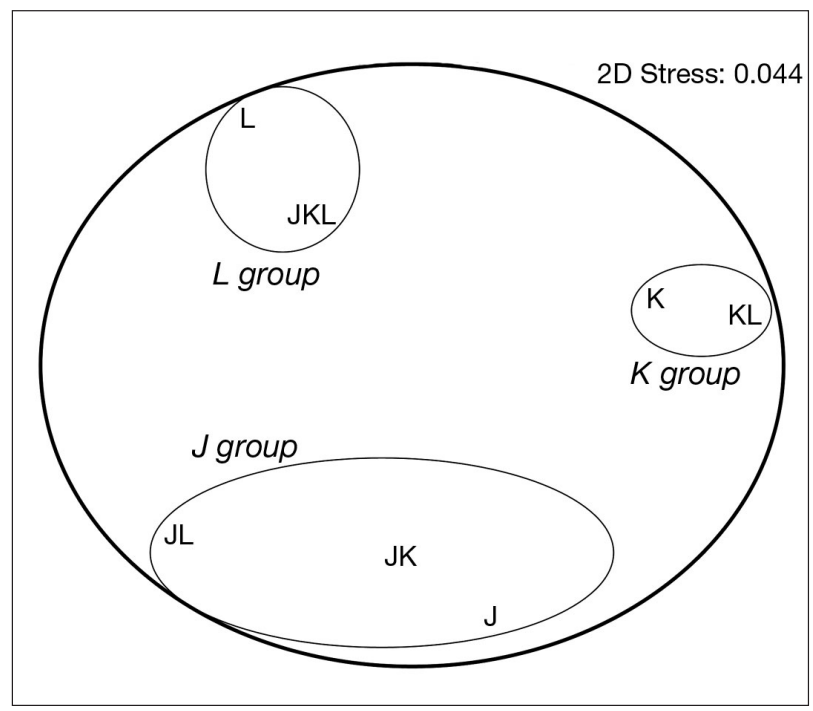

Fig. 2. Orcinus orca. Two-dimensional NMDS scaling configuration of similarities among pod combinations based on standardized Bray-Curtis similarity indices for spatially-referenced densities of each pod combination; groupings from hierarchal clustering superimposed (stress $=0.04$ ). Pod combinations with more similar kernel density distributions are closer together. Dashed line at $70 \%$ similarity indicates complete group (all pod combinations); 3 groups at $75 \%$ similarity shown by thin lines and italicized group names ( $\mathrm{J}, \mathrm{K}$, and L groups). Pod combinations indicated with non-italic capital letters
Strait, but distinctions in space use were notable for $\mathrm{J}$ and $\mathrm{L}$ groups. In contrast to the other 2 pod groups, the $\mathrm{J}$ group exhibited higher density ranging further north, with extensive use of Swanson Channel into Active Pass (Fig. 3). In addition, the J group exhibited higher density further east (south of San Juan and Lopez Islands) and north into Rosario Strait. The L group showed the greatest variation in space use, with rather extensive use of the Strait of Juan de Fuca, off southern Vancouver Island. The J and K groups rarely used the Strait of Juan de Fuca (Fig. 3). The L group also appeared to use Boundary Pass rather than Swanson Channel and Active Pass. The K group's use of space appeared to be an intermediate form of J and L groups (Fig. 3). Their use of Swanson Channel, Active Pass and Boundary Pass, respectively, was nearly equal, with no extensive use of any other area.

Both the $\mathrm{J}$ and $\mathrm{L}$ groups used regions at the highest density classes that other pod groups simultaneously used at the lowest density classes (Fig. 4). No such

Table 2. Orcinus orca. Number of sighting days for each pod group, pod and pod combination and percent of days sighted relative to potential availability throughout the study period (1996 to 2001). Parentheses: pod combinations pooled by multivariate analyses

\begin{tabular}{|lcc|}
\hline $\begin{array}{l}\text { Pod group, pod } \\
\text { or pod combination }\end{array}$ & $\begin{array}{c}\text { Total days } \\
\text { sighted }\end{array}$ & $\begin{array}{c}\text { \% days sighted/ } \\
\text { days available }\end{array}$ \\
\hline J group (J, JK, JL) & 379 & 48.8 \\
J & 177 & 22.8 \\
JK & 156 & 20.1 \\
JL & 46 & 5.9 \\
K group (K, KL) & 157 & 20.2 \\
K & 112 & 14.4 \\
KL & 45 & 5.8 \\
L group (L, JKL) & 473 & 61.0 \\
L & 302 & 38.9 \\
JKL & 171 & 22.0 \\
\hline
\end{tabular}



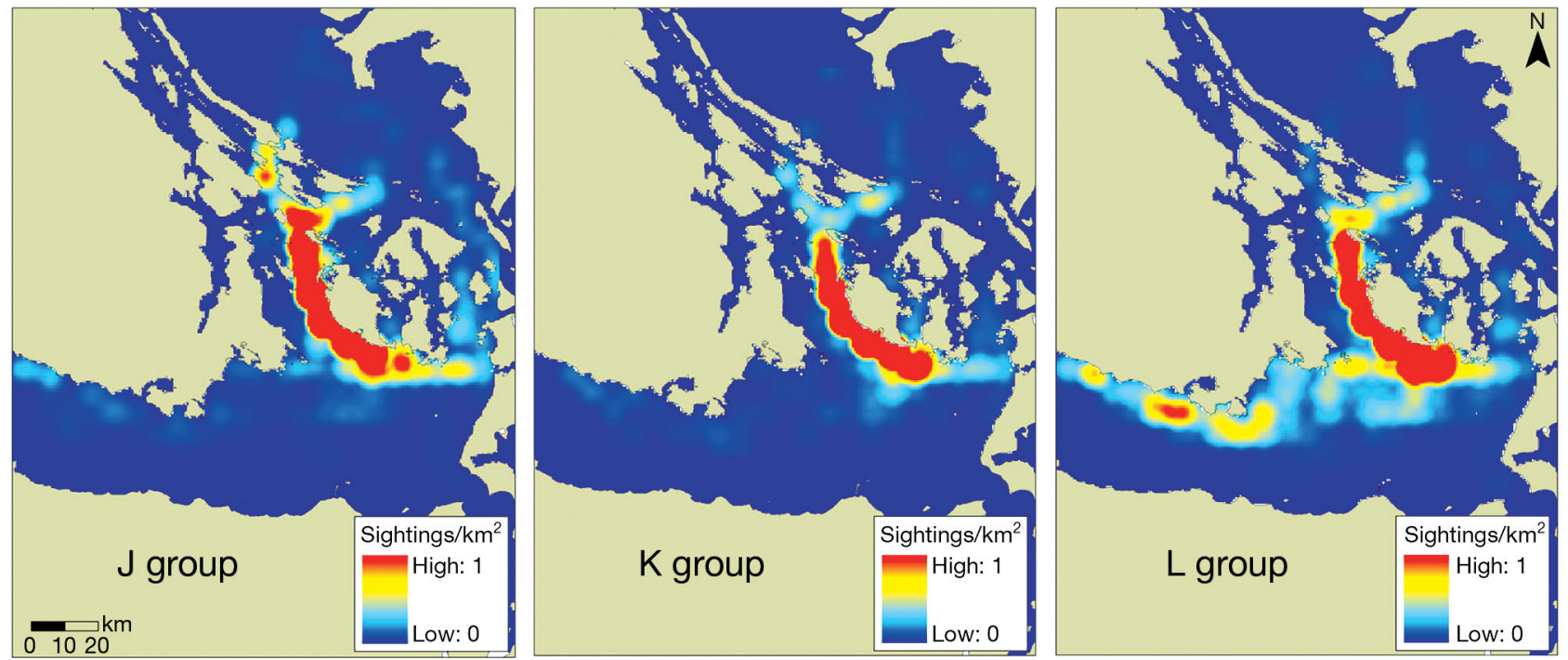

Fig. 3. Orcinus orca. Kernel density distributions for J, K and L groups, normalized as proportion of maximum density. Observation effort corrected using recommendations in Hauser et al. (2006)

specialization was identified for the $\mathrm{K}$ group. The $\mathrm{J}$ group specialized in northern Rosario Strait and near Active Pass, while the L group specialized south of Vancouver Island in the Strait of Juan de Fuca. All 3 pod groups also used several common areas, which had matching density classifications across all pod groups (Fig. 4). All 3 pod groups shared highest use in Haro Strait, a common core region. This highest use area (81-100\% sightings) was also the largest shared region, covering $360 \mathrm{~km}^{2}$, followed in succession by each lower shared-use category (the $61-80 \%$ use class was $116 \mathrm{~km}^{2}, 41-60 \%$ was $69 \mathrm{~km}^{2}, 21-40 \%$ was $53 \mathrm{~km}^{2}$, and the lowest use category comprised $31 \mathrm{~km}^{2}$ ). The common core region in Haro Strait was primarily a single, large, connected area, whereas the other shared areas were discontinuous and patchily distributed. Each pod group also shared regions that were never used (zero density). Beyond the common core region, pod-specific core areas varied according to the general distribution patterns described above (Fig. 4). The J and K groups shared some core regions surrounding the common core area to the north and south. The J group's core region extended into Swanson Channel; that of the K group largely overlapped with the common core except for a small extension in Boundary Pass. Additional core areas for the L group were identified in the Strait of Juan de Fuca south of Vancouver Island.

The geographic distributions quantitatively summarized the descriptive differences in each group's space use. The mean center for each pod group was slightly displaced from the pooled SRKW mean center, with the $\mathrm{J}$ group displaced the furthest in a northeastern direction (Table 3). The K group's mean center, closest to the pooled SRKW mean center and at the smallest angle from it (almost directly east), showed the least displacement. The L group's mean center was displaced to the southwest of the pooled SRKW mean center. However, comparing dispersion from the mean center among pod groups yielded the greatest variation in geographic distribution. The L group's directional distribution was largest, but its orientation was most similar to that of the pooled SRKW distribution along a northeast-southwest axis. The K group's distribution, with the smallest total area, was the most concentrated around its mean center.

\section{DISCUSSION}

This study aimed to identify the fine-scale summer use of British Columbia and Washington inshore waters by population segments of endangered SRKW, using an extensive database of sightings contributed by a centralized network of commercial whalewatchers. A cross-validation study using independent observers allowed us to establish rules for subsampling this database to remove the effects of spatial differences in observation effort, time of day, and pod identification accuracy (Hauser et al. 2006). Thus, observer effort was evaluated quantitatively, allowing us to conclude that observed high SRKW use is not simply a result of high observer effort.

This was the first long-term, fine-scale study identifying spatially-explicit overlap and variation among fish-eating killer whale pods and the core areas of their 

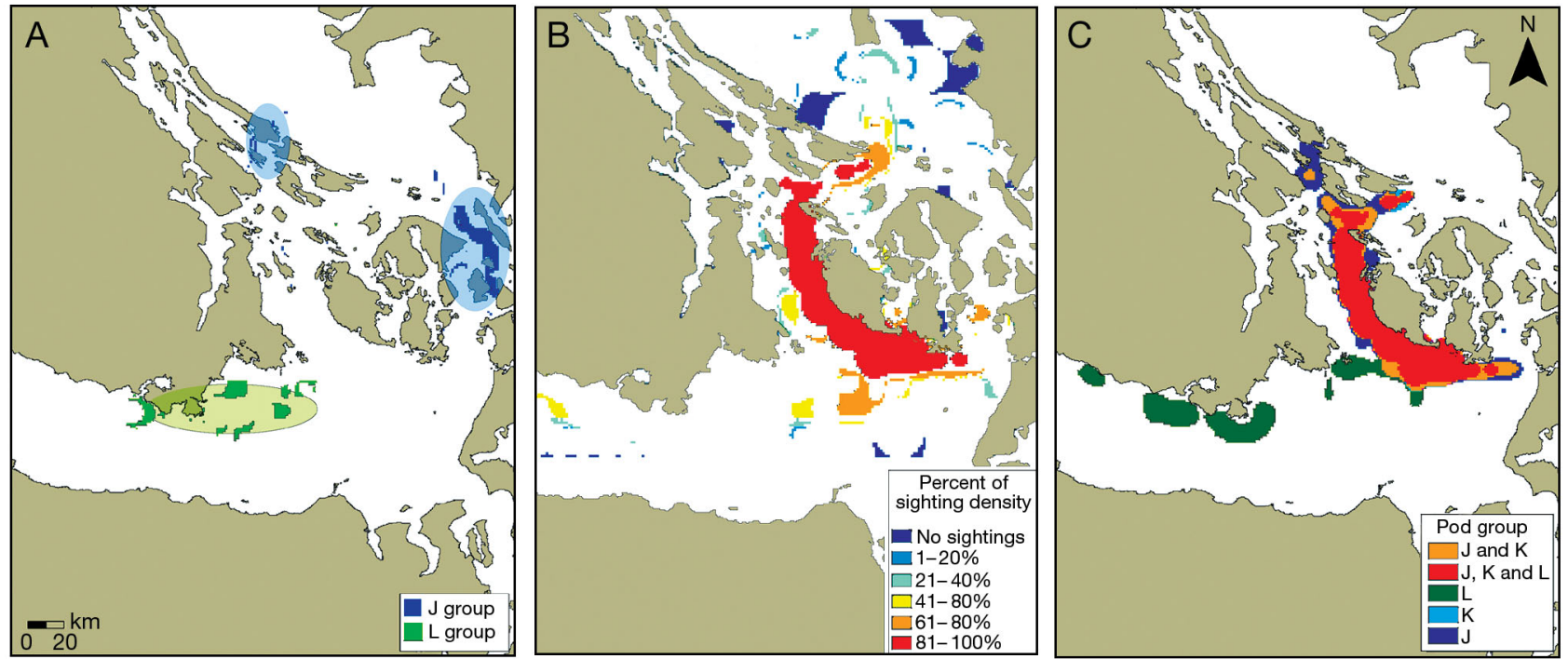

Fig. 4. Orcinus orca. (A) Locations representing specialization by pod group (i.e. regions classified as high density by one pod group while simultaneously classified at low density for all others). Overlaid ovals are generalized regions of specialization based on the exact identified locations. No areas of specialization for K group. (B) Common space use among all pod groups. Note that regions commonly classified as highest density class are also considered a common core region among all pod groups. (C) Core area location among pod groups, including areas that are independently classified as core by 2 or more pod groups

range. We found specific core areas used by all SRKW social groups as well as areas used in a specialized manner among individual groups. Our analysis indicates that all pods spend a disproportionate amount of time in the largest and most contiguous core area in the Haro Strait region along the west side of San Juan Island, ranging north into Boundary Pass. The L pod group had the most extensive and widest-ranging variation from the common core area, extensively using the Strait of Juan de Fuca near the south side of Vancouver Island. Thus this research documents the existence of core areas that are disproportionately used by either individual pod groups or across all pods in this endangered population. Our analysis focused on SRKW distribution patterns within inshore waters of Washington and British Columbia; while this area is obviously a prominent component of SRKW summer range, with SRKW spending $80 \%$ of summer days there, the other $20 \%$ of their summer range and their winter distributions almost certainly contain key habitats and warrant continued research.

It remains unclear whether common core areas represent areas of foraging, traveling, or socializing. Additional research that combines observed distribution patterns with behavioral observations could provide information on this question. Functional use of particular areas, such as foraging, could then be linked to core areas (Hastie et al. 2004). Prey availability and distribution likely affect SRKW pod distribution. The Chinook salmon Oncorhynchus tshawytscha appears to be the primary summer prey of SRKW, but the whales also - at least occasionally - feed on other salmonids and bottomfish (Ford et al. 1998, Ford \& Ellis 2006). There is no information on pod-specific diet other than similar vertical use of the water column (Baird et al. 2005) and diet studies are limited to a small

Table 3. Orcinus orca. Spatial central tendency for J, K, and L pod groups and all SRKW, including mean center and 1 SD dispersion from mean center

\begin{tabular}{|c|c|c|c|c|c|c|}
\hline \multirow{2}{*}{ Pod grouping } & \multicolumn{2}{|c|}{ Mean center } & \multicolumn{4}{|c|}{ Dispersion from mean center (1 SD) } \\
\hline & $\begin{array}{c}\text { Distance from } \\
\text { SRKW mean }(\mathrm{km})\end{array}$ & $\begin{array}{c}\text { Angle from } \\
\text { SRKW mean }\left({ }^{\circ}\right)\end{array}$ & $\begin{array}{l}\text { Total area } \\
\left(\mathrm{km}^{2}\right)\end{array}$ & $\begin{array}{c}\text { X standard } \\
\text { distance }(\mathrm{km})\end{array}$ & $\begin{array}{c}\text { Y standard } \\
\text { distance }(\mathrm{km})\end{array}$ & $\begin{array}{l}\text { Rotation } \\
\text { angle }\left({ }^{\circ}\right)\end{array}$ \\
\hline $\mathrm{J}$ & 5.623 & 65.059 & 875699 & 16.834 & 16.559 & 346.750 \\
\hline $\mathrm{K}$ & 4.019 & 13.724 & 643778 & 14.830 & 13.819 & 308.203 \\
\hline $\mathrm{L}$ & 4.522 & -125.122 & 1016679 & 14.789 & 21.884 & 292.957 \\
\hline All SRKW & - & - & 973009 & 15.754 & 19.661 & 295.563 \\
\hline
\end{tabular}


number of SRKW surface observations. It is possible that core areas represent prey hotspots for SRKW. However, we do not currently have sufficient information on SRKW diet, potential slight dietary variations among pods, effects of environmental conditions (e.g. temperature, bathymetry, climate, and tidal cycles) on SRKW foraging ability or prey movement, or on prey distribution to address effects of prey presence on SRKW distribution.

Next, we considered variations in distribution among pods. Different pods often intermingle for brief periods (described as 'pod combinations' in this study), likely for socialization and possibly reproduction between pods. By applying 2 multivariate techniques, we allowed pod combinations to naturally cluster into groups and used these groups for analyses. Although results of the 2 approaches corroborate one another, it should be noted that a somewhat subjective similarity level is used to determine groupings. A common problem for clustering techniques is the difficulty of choosing an objective number of groups to accept (McGarigal et al. 2000), but accuracy in groupings can be verified by superimposing hierarchal clustering results on the NMDS ordination (Clarke \& Warwick 2001). By combining clustering and ordination techniques, we present an effective method for examining the adequacy and mutual reliability of groupings by both analyses. At $70 \%$ similarity, space use of all 7 pods and pod combinations could not be dependably grouped. However, 3 groups were identifiable as similarity increased to $75 \%$. The next hierarchical break into 6 groups occurred at $85 \%$ similarity. This suggests that space use of all pod combinations cannot be distinguished at low similarity coefficient values, but distribution patterns of pod combinations can be reliably pooled above $75 \%$. With this assumption, we investigated the questions of pod-distribution similarities and differences using 3 pod groupings.

Social association patterns may be an important factor affecting how the pod combinations cluster into pod groups and how these pod groups use space differently. While molecular data are not available to describe relatedness among SRKW pods, our pod groupings align with analyses of pod acoustical similarities and association patterns via photographic matching (Ford 1991, Ford et al. 2000). Social affiliations in pod groups may provide an indication of potential dominance and separation among pods. Distribution patterns of all $\mathrm{J}$ pod combinations (other than J, K, and L combined) were most closely matched to the $\mathrm{J}$ pod alone. Thus, it appears that the J pod may be driving movement and space use when combined with the $\mathrm{K}$ and L pods. Likewise, the K pod's distribution patterns were associated with the $\mathrm{K}$ and $\mathrm{L}$ pod combination, indicating that the $\mathrm{K}$ pod has the most influence on space use patterns when those 2 pods combine. However, when all 3 pods combine, distribution patterns most closely resemble those of the L pod alone. Mechanisms allowing for space partitioning among pod groups (such as social learning or other behaviors) were beyond the scope of this research but may contribute to the spatial distributions described here.

Many locations were found to be used uniquely among pod social groups. Both the J and L groups had unique individual core areas outside of the common core region. Each of these 2 pod groups also frequently used locations that were simultaneously used at low levels by the other 2 pod groups. These distinctions are likely to be the consequence of some fundamental difference among pods, like foraging specializations or preferences for particular habitat characteristics. For example, pod-specific foraging specializations and resultant variations in space use have been described for mammal-eating transient killer whales within the same region (Baird \& Dill 1995). Currently we have insufficient information to compare diets of different SRKW pod groups, but this may be an important consideration in understanding pod-specific distribution patterns. Social groups of other cetacean populations are also known to segregate space use, which has been linked to differential foraging success or reproductive status (Ersts \& Rosenbaum 2003, Whitehead \& Rendell 2004). While associations to foraging and reproduction cannot be made here, these remain important potential implications of pod-specific space use.

Slight variations in foraging ability or prey availability in different core areas among SRKW pods may contribute to the observed differences in pod population trends and mortality rates, thus affecting population viability. The L pod, in particular, has both lower survival rates than the $\mathrm{J}$ and $\mathrm{K}$ pods and the most direct influence on overall SRKW population trends, primarily because of its large size (nearly 2 times larger) relative to the other 2 pods (Ford et al. 2000, Baird 2001, Krahn et al. 2004). Thus, the L pod represents a potential conservation target pod and protection actions in $\mathrm{L}$ group core areas could lead to benefits for overall SRKW population recovery. In this study, the L group showed some different space use patterns than the J and K groups. The L group also exhibited the least concentrated space use around the common core area and the greatest dispersion from the centralized high use Haro Strait core areas. This suggests that the L group may be largely driving overall space use among SRKW. Several factors could be motivating these patterns, including an increased search effort for resources, larger pod size, or further divisions in the social structure of the L pod. Many cetaceans require additional movement and dispersion to locate and pro- 
cure prey as resources become sparse (e.g. Jaquet \& Whitehead 1999). It is certainly possible that SRKW are experiencing lower densities of their target prey species. Several wild stocks of the Chinook salmon Oncorhynchus tshawytscha and other salmonid species are endangered or at risk in this region and exhibit decreasing size with age over time (National Research Council 1996). In addition, McCluskey (2006) suggests that SRKW, in general, have more complex, broader movement patterns during periods of population decline than growth. However, unless the $\mathrm{L}$ pod is foraging on a unique prey species or population, it is unlikely that prey availability would drive greater L group dispersion relative to that of other pod groups. The L pod's larger group size may also simply require the greater overall space use and dispersion documented here. However, prey concentration also affects predator dispersion. Larger groups of predators may have to disperse more widely so that all members of the group can forage successfully, which may be why the L pod - the largest SRKW pod - has the greatest dispersion. Traditionally, most studies have recognized only the J, K, and L pods among SRKW, but increasing evidence shows that the L pod has actually divided into 2 different pods that fit the Bigg et al. (1990) pod definition (Baird et al. 2005). The available data provided insufficient information to determine if the L subpods exhibited distinct distribution patterns, but it is possible that the L group's extensive space use and specializations really reflect the differences between distinct L subgroups. A combination of some or all of these factors may contribute to the L group's distribution patterns, but the ultimate cause remains unclear.

Each pod may be exposed to different levels of risk factors within the specialized portions of their summer range. Prey quality and quantity, toxins, vessel impacts, random small population fluctuations, or cumulative effects are most frequently implicated in SRKW declines (Baird 2001, Krahn et al. 2004, Ross 2006). Furthermore, distribution patterns of many marine mammal predators are affected by annual variability in climate, tidal cycles and other ocean processes, and the resulting impacts on prey (Keiper et al. 2005, MacLeod et al. 2005). Effects of a changing climate on SRKW survival, prey, and habitat are unknown, but slight variations in pod summer range should be further researched for continued conservation of this endangered population.

This study provides 2 key relevant conclusions. First, some regions of the SRKW summer range are more important than others, at least in terms of frequency of use. Haro Strait is a key area used more frequently by all pods than any other region in the summer range. Accordingly, it seems appropriate to focus potential habitat protection, use restrictions, or other conserva- tion measures within this region for the greatest benefit to all pods. Second, the L pod, which has declined the most in the past $10 \mathrm{yr}$, uses part of the summer range differently. The $\mathrm{L}$ pod, unlike the other 2 smaller pods, frequently uses the Strait of Juan de Fuca and ranges more widely. These results emphasize potential areas where human-whale conflicts may occur within key components of SRKW distribution. Depending upon management goals, this work provides the necessary descriptive framework for pod-specific protected areas and conservation initiatives.

Acknowledgements. Commercial whale watch data were compiled and maintained by the Whale Museum in Friday Harbor, WA. J. Olson provided initial spatial data preparation and management. Many years of dedicated annual censuses by K. Balcomb and the Center for Whale Research have allowed for individual identification of SRKW and knowledge of animal association patterns. S. Wang and P. Westley provided suggestions for multivariate statistical analyses and interpretation. This manuscript was considerably improved by editorial suggestions from R. W. Baird, D. Noren, P. Westley, M. Ford, and 3 anonymous reviewers. This research was funded by the Northwest Fisheries Science Center, National Marine Fisheries Service, and additional support was provided by the Washington Cooperative Fish and Wildlife Research Unit. The use of trade, product, or firm names in this publication is for descriptive purposes only and does not imply endorsement by the US Government.

\section{LITERATURE CITED}

Baird RW (2001) Status of killer whales, Orcinus orca, in Canada. Can Field-Nat 115:676-701

Baird RW, Dill LM (1995) Occurrence and behaviour of transient killer whales: seasonal and pod-specific variability, foraging behaviour and prey handling. Can J Zool 73: 1300-1311

Baird RW, Stacey PJ (1988) Variation in saddle patch pigmentation in populations of Killer Whales (Orcinus orca) from British Columbia, Alaska, and Washington State. Can J Zool 66:2582-2585

Baird RW, Hanson MB, Dill LM (2005) Factors influencing the diving behaviour of fish-eating killer whales: sex differences and diel and inter-annual variation in diving rates. Can J Zool 83:257-267

Bigg MA, Ellis GM, Ford JKB, Balcomb KC (1987) Killer whales: a study of their identification, genealogy, and natural history in British Columbia and Washington State, Phantom Press, Nanaimo

Bigg MA, Olesiuk PF, Ellis GM, Ford JKB, Balcomb KC (1990) Social organization and genealogy of resident killer whales (Orcinus orca) in the coastal waters of British Columbia and Washington State. Rep Int Whal Comm (Special Issue) 12:383-405

Bray JR, Curtis JT (1957) An ordination of upland forest communities of southern Wisconsin. Ecol Monogr 27:325-349

Clarke KR (1993) Non-parametric multivariate analyses of changes in community structure. Aust J Ecol 18:117-143

Clarke KR, Warwick RM (2001) Change in marine communities: an approach to statistical analysis and interpretation, 2nd edn. Primer-E, Plymouth

Dobson A, Poole J (1998) Conspecific aggregation and conservation biology. In: Caro T (ed) Behavioral ecology 
and conservation biology. Oxford University Press, New York, p 193-208

Ersts PJ, Rosenbaum HC (2003) Habitat preference reflects social organization of humpback whales (Megaptera novaeangliae) on a wintering ground. J Zool Soc Lond 260:337-345

Ford JKB (1991) Vocal traditions among resident killer whales (Orcinus orca) in coastal waters of British Columbia. Can J Zool 69:1454-1483

Ford JKB, Ellis GM (2006) Selective foraging by fish-eating killer whales Orcinus orca in British Columbia. Mar Ecol Prog Ser 316:185-199

Ford JKB, Ellis GM, Barrett-Lennard LG, Morton AB (1998) Dietary specialization in two sympatric populations of killer whales (Orcinus orca) in coastal British Columbia and adjacent waters. Can J Zool 76:1456-1471

Ford JKB, Ellis GM, Balcomb KC (2000) Killer whales, UBC Press, Vancouver

Forney KA (2000) Environmental models of cetacean abundance: reducing uncertainty in population trends. Conserv Biol 14:1271-1286

Haining R (2003) Spatial data analysis. Cambridge University Press, Cambridge

Hastie GD, Wilson B, Wilson LJ, Parsons KM, Thompson PM (2004) Functional mechanisms underlying cetacean distribution patterns: hotspots for bottlenose dolphins are linked to foraging. Mar Biol 144:397-403

Hauser DDW (2006) Summer space use of southern resident killer whales (Orcinus orca) within Washington and British Columbia. MSc thesis, University of Washington, Seattle, WA

Hauser DDW, VanBlaricom GR, Holmes EE, Osborne RW (2006) Evaluating the use of whalewatch data in determining killer whale (Orcinus orca) distribution patterns. J Cetacean Res Manag 83:273-281

Heide-Jorgensen MP, Dietz R, Laidre KL, Richard P (2002) Autumn movements, home ranges, and winter density of narwhals (Monodon monoceros) tagged in Tremblay Sound, Baffin Island. Polar Biol 25:331-341

Hobbs RC, Laidre KL, Vos DJ, Mahoney BA, Eagleton M (2005) Movements and area use of belugas, Delphinapterus leucas, in a subarctic Alaskan estuary. Arctic 58: 331-340

Hoelzel AR, Osborne RW (1986) Call characteristics of killer whales, implications for cooperative foraging. In: Kirkevold B, Lockard JS (eds) Behavioral biology of killer whales. Alan R. Liss, New York, p 373-403

Jaquet N, Whitehead H (1999) Movements, distribution and feeding success of sperm whales in the Pacific Ocean, over scales of days and tens of kilometers. Aquat Mamm 25:1-13

Keiper CA, Ainley DG, Allen SG, Harvey JT (2005) Marine

Editorial responsibility: Rory Wilson (Contributing Editor), Swansea, UK mammal occurrence and ocean climate of central California, 1986 to 1994 and 1997 to 1999. Mar Ecol Prog Ser 289: 285-306

Krahn MM, Ford MJ, Perrin WF, Wade PR and 6 others (2004) Status review of southern resident killer whales (Orcinus orca) under the Endangered Species Act. US Department of Commerce, NOAA Technical Memorandum NMFSNWFSC-62, Seattle, WA

Kruskal JB (1964) Nonmetric multidimensional scaling: a numerical model. Psychometrika 29:28-42

MacLeod CD, Bannon SM, Pierce GJ, Schweder C, Learmonth JA, Herman JS, Reid RJ (2005) Climate change and the cetacean community of north-west Scotland. Biol Conserv 124:477-483

McCluskey (2006) Population trends and movement complexity patterns of southern resident killer whales (Orcinus orca) in relation to Pacific salmon (Oncorhynchus spp.) in the inland waters of Washington State and British Columbia. MSc thesis, University of Washington, Seattle, WA

McGarigal K, Cushman S, Stafford S (2000) Multivariate statistics for wildlife and ecology research. Springer Verlag, New York

Mitchell A (2005) GIS Analysis, Vol 2: Spatial measurements \& statistics. ESRI Press, Redlands, CA

National Research Council (1996) Upstream: salmon and society in the Pacific Northwest. National Academies Press, Washington, DC

Osborne RW (1999) A historical ecology of Salish Sea resident killer whales (Orcinus orca) with implications for management. $\mathrm{PhD}$ dissertation, University of Victoria

Redfern JV, Ferguson MC, Becker EA, Hyrenbach KD and 15 others (2006) Techniques for cetacean-habitat modeling. Mar Ecol Prog Ser 310:271-295

Ross PS (2006) Fireproof killer whales (Orcinus orca): flameretardant chemicals and the conservation imperative in the charismatic icon of British Columbia, Canada. Can J Fish Aquat Sci 63:224-234

Samuel MD, Pierce DJ, Garton EO (1985) Identifying areas of concentrated use within the home range. J Anim Ecol 54: $711-719$

Silverman BW (1986) Density estimation for statistics and data analysis. Chapman \& Hall, New York

Whitehead H (1997) Analyzing animal social structure. Anim Behav 53:1053-1067

Whitehead H, Rendell L (2004) Movements, habitat use and feeding success of cultural clans of South Pacific sperm whales. J Anim Ecol 73:190-196

Worton BJ (1989) Kernel methods for estimating the utilization distribution in home-range studies. Ecology 70: 164-168

Submitted: February 19, 2007; Accepted: June 21, 2007

Proofs received from author(s): October 25, 2007 